\title{
KOMUNIKACIJA
}

\section{TINKLARAŠČIAI KAIP POLITINĖS KOMUNIKACIJOS IৃANKIS: LIETUVOS RESPUBLIKOS SEIMO NARIŲ ATVEJIS}

\author{
Dr. ANDRIUs Šuminas
}

Vilniaus universiteto Komunikacijos fakultetas

Mediju tyrimu laboratorijos vedejjas

Vilnius University Faculty of Communication

Head of Media Research Lab

Sauletekio al. 9, LT-10222 Vilnius

El.paštas andrius.suminas@kf.vu.lt

\section{Santrauka}

Tinklaraščiai žymi interaktyviujų mediju issigalèjimo politinès komunikacijos procesuose pradžiq, suteikusia nauju galimybiu praplesti politinio diskurso lauka ir prieinamuma ịvairioms suinteresuotoms grupems ar pavieniams individams. Dabartiniu metu pasaulyje politiku tinklaraščiai yra tape įprastu reiškiniu, padedančiu politiniams veikejjams užmegzti ir išlaikyti kontaktus su naujomis potencialiu rinkejų auditorijomis, taip pat palaikyti nuolatinị abipusį ryši tarp politiku ir visuomenés. Šiame straipsnyje nagrinèjamos tinklaraščiu taikymo galimybès politinès komunikacijos procesuose, analizuojamos interakcijos šiuose virtualiuose kanaluose ypatybès. Straipsnyje konkrečiai apibrëžiamos bendros tinklaraščį charakteristikos ir juos apibūdinančios savybès, išskiriami skirtingi ju tipai ir galimi analizes matmenys. Taip pat detaliai analizuojama tinklarašči politikams suteikiama nauda, nagrinèjamas politiniu tinklaraščiu ir tradicines žiniasklaidos santykis bei tarpusavio sąsajos. Publikacijos pabaigoje pateikiami Lietuvos Respublikos Seimo nariu naudojimosi tinklaraščiais 
tyrimo rezultatai, atskleidžiantys menka šios interaktyvios priemonès išnaudojima politinès komunikacijos tikslams mūsų šalyje.

Reikšminiai žodžiai: tinklaraščiai; politikų tinklaraščiai; politinė komunikacija; Seimo narių komunikacija; tinklaraščių charakteristikos.

Tinklaraščių ir wiki puslapių atsiradimas žymi antrosios kartos žiniatinklio (angl. web 2.0) pradžią, kai didžioji dalis paslaugų ir turinio kontrolès buvo perleista patiems naudotojams, leidžiant jiems laisvai kurti ir naudotis informacija bei duomenimis, kartais net suteikiant galimybę keisti informacinių sistemų struktūras.

Itvairios socialinių medijų priemonès, apibūdinančios interaktyvias technologijas ir būdus, kuriais individai sąveikauja tarpusavyje dalydamiesi savo sukurtu turiniu, greitai tapo itin populiarios tarp interneto naudotojų, todèl nenuostabu, kad demesị atkreipti $\mathfrak{i}$ jas netruko ir politikai. Šiandien ịvairios socialinių medijų priemonès jau yra tapusios neatskiriama daugelio politikų kasdieninès komunikacijos dalimi, o būtent tinklaraščius turètume laikyti interaktyviosios politinès komunikacijos pirmosiomis kregždèmis.

\section{Tinklaraščiu apibrèžtis ir pagrindinės ypatybès}

Nors nuo pirmųjų tinklaraščių (angl. blogs) atsiradimo praejo jau beveik dvidešimt metų, tačiau iki šiol nèra vieno aiškiai apibrèžto ir visuotinai pripažįstamo šio internetinès erdvès kanalo apibrèžimo. Mokslininkai ir praktikai apibrèždami tinklaraščių sąvoką akcentuoja šiek tiek skirtingus šių priemonių aspektus, dėmesị labiau kreipdami arba ị kanalo charakteristikas, arba ị individų, tai yra tinklaraštininkų ir jų skaitytojų, sąveiką.

Dažniausiai tinklaraščiai apibrèžiami kaip virtualūs dienoraščiai, kuriuose reguliariai skelbiama ir atnaujinama informacija, dèstoma at- 
virkštine chronologine tvarka ${ }^{1}$. Ivairiuose tinklaraščių apibrèžimuose taip pat dažnai akcentuojamas informacijos apsikeitimas ir sąveika tarp virtualios erdvės dalyvių, tai yra tarp tinklaraščių rašytojų ir jų skaitytojų. Apibendrinant skirtingus moksliniuose šaltiniuose pateikiamus tinklaraščių apibrèžimus galima išskirti dažniausiai minimas pagrindines tinklaraščių charakteristikas:

1. Atvirkščiai chronologiška ịrašų tvarka. Tinklaraščiuose įrašai dèstomi pagal atvirkštinę chronologiją - naujausi įrašai visada būna tinklaraščių viršuje, pačioje matomiausioje vietoje.

2. Skaitytojų komentarai. Daugumoje ịvairiais aspektais tinklaraščius analizuojančių mokslinių publikacijų pabrèžiama, kad skelbiamų įrašų komentavimo galimybės yra būtinas tinklaraščių atributas. Be irašų skaitytojų komentavimo galimybès tinklalapis negali būti (iki galo) laikomas tinklaraščiu ${ }^{2}$.

3. Nuorodos ị kitus tinklaraščius (angl. blogrolls). Tinklaraščiuose dažniausiai pateikiamos nuorodos ị kitus tinklaraščius, tinklalapius, forumus ar pan., taip tinklaraščiai tampa susieti ir priklausomi vieni nuo kitų, kai kurie iš jų tampa sąsajų centrais (turinčiais daugiausia sąsajų su kitais tinklaraščiais ar kitomis medijomis) ${ }^{3}$.

4. Sąsajos įrašuose (angl. tags). Tinklaraštininkai savo įrašus konkrečioms tematinėms kategorijoms priskiria naudodami žymas. Jos leidžia susieti skirtingus tos pačios tematikos tinklaraščių ịrašus, o skaitytojams palengvina prieigą prie susijusio turinio.

5. Irašų archyvai. Daugumoje tinklaraščių galima rasti kalendorinius arba tematinius įrašų archyvus, kurie skaitytojams gerokai palengvina paiešką pagal laiką arba tematiką.

1 Lawson-Borders, G., Kirk, R. Blogs in Campaign Communication. American Behavioral Scientist. 2005, vol. 49, No. 4, p. 548-559.

2 Quiggin, J. Blogs, wikis and creative innovation. International Journal of Cultural Studies. 2006, vol. 9, p. 481-496.

3 Gil De Zúñiga, H., Puig-I-Abril, E., Rojas, H. Weblogs, traditional sources online and political participation: an assessment of how the internet is changing the political environment. New Media Society. 2009, vol. 11, p. 553-574. 
6. Reguliari komunikacija. Kalbant apie tinklaraščius dažnai pabrěžiamas nuolatinis komunikacijos ir interakcijos vyksmas, todèl juose turi būti nuolat reguliariai publikuojamas naujas turinys.

Patys tinklaraščių skaitytojai apibūdindami tinklaraščius dažniau pabrèžia ne struktūrines jų ypatybes, o interakcijos galimybes ${ }^{4}$. Tinklaraščius skaitantiems žmonèms svarbiausios yra tiesioginio informacijos gavimo, komentavimo ir nevaržomų diskusijų galimybės.

Nuo pat tinklaraščių atsiradimo pradžios interaktyvios tinklaraščių savybès, tokios kaip galimybès komentuoti ịrašus, nuorodos ị kitus tinklaraščius ir tarpusavio sąsajos, buvo ịvardijamos kaip pagrindinis tinklaraščių išskirtinumas. Tačiau dabartiniu metu šie interaktyvūs atributai jau nèra būdingi tik tinklaraščiams, nes ir kitos virtualios priemonès pasižymi šiomis savybėmis, pavyzdžiui, kai kurie tinklalapiai, diskusijų forumai ir pan.

Pirmuoju pasaulyje tinklaraščiu laikomas amerikiečių studento Justino Hallo 1994 metais pradètas rašyti internetinis dienoraštis apie kompiuterinius žaidimus ir žaidimų kompiuterius. Tinklaraščius apibūdinantį anglišką terminą „weblog“ 1997 metais pasiūlė Jornas Bargeris, nuo angliško termino „logging the web“. Terminas prigijo ir pradejo sparčiai plisti, o 1999 metais sutrumpejo dar dviem raidemis - iki dabar anglų kalboje vartojamo „blog“.

Tinklaraščiai ne iš karto tapo masiniu reiškiniu, nes norintys juos rašyti turejo susikurti specialų tinklalapi, o tam padaryti reikejo turèti bent šiokius tokius programavimo pagrindus. Internetinių dienoraščių populiarumui didelị postūmị suteikẻ 1999 metais veiklą pradèjusios specializuotos platformos, skirtos rašyti tinklaraščius - Blogger.com ir LiveJournal.com, kurios leido jokių programavimo ar techninių žinių netu-

4 Ekdale, B., Namkoong, K., Fung, T.K.F, Perlmutter, D.D. Why blog? (then and now): exploring the motivations for blogging by popular American political bloggers. New Media Society. 2010, vol. 12, No. 2, p. 217-234. 
rintiems interneto naudotojams lengvai susikurti ir rašyti tinklaraščius ${ }^{5}$.

Šiuo metu internetinius dienoraščius rašančių žmonių patogumui savo paslaugas siūlo daugybė tarptautinių ir lokalių platformų, skirtų tinklaraščiams rašyti. Pavyzdžiui, 2012 metų antroje pusejje populiariausia pasaulinè specializuota tinklaraščiu platforma Blogspot.com buvo 11 tinklalapis pasaulyje pagal unikalių lankytojų skaičių ${ }^{6}$ o lankomiausia lietuviška tinklaraščiams rašyti skirta platforma Blogas.lt pritraukdavo daugiau negu 250 tūkstančių unikalių lankytojų kiekvieną mėnesị ${ }^{7}$.

Tiek tinklaraščių atsiradimo pradžioje, tiek dabartiniu metu tinklaraščiai suvokiami kaip autentiškos ir neredaguojamos informacijos kanalas, kuriame įrašai pateikiami būtent tokia forma, kokia juos skelbia tinklaraštininkas, ir nèra niekieno daugiau redaguojami. Būtent tuo tinklaraščiai skiriasi nuo tradicinès žiniasklaidos, nes čia informacija gali būti pateikiama nesivadovaujant žiniasklaidos priemonèms būtinais principais, tokiais kaip požiūrių ir nuomonių pusiausvyra, faktais patikrinta informacija ir pan.

Jeigu tradicinès žiniasklaidos priemonèse dominuoja ar bent jau turètų dominuoti faktai ir objektyvumas, tai tinklaraščiuose - nuomonès, vertinimai ir subjektyvumas. Priešingai negu didžioji dalis žiniasklaidos turinio, tinklaraščiuose skelbiami ịrašai nebūtinai turi būti susiję su naujausiomis aktualijomis. Tačiau tinklaraščius rašantys asmenys dažniausiai apsibrèžia vieną konkrečią sritị, kurioje ir specializuojasi.

Kartais pabrěžiama, kad tinklaraščiams yra būdinga sakytinè kalbos forma, tik pateikiama tekstu. Tai yra tarsi tarpiné grandis tarp kalbinès

5 Jones, J., Himelboim, I. Just a guy in pajamas? Framing the blogs in mainstream US newspaper coverage (1999-2005). New Media Society. 2010, vol. 12, No. 2, p. 271-288.

6 The top 500 sites on the web. Alexa Internet, Inc. The Web Information Company. Prieiga per internetą: <http://www.alexa.com/topsites > [žiūrèta $2012 \mathrm{~m}$. lapkričio 19 d.].

7 GemiusAudience tyrimai. UAB „Gemius Baltic“. Prieiga per internetą: <http:// www.audience.lt/pages/display/visitors> [žiūrèta 2012 m. lapkričio 19 d.]. 
ir rašytinès raiškos ${ }^{8}$. Pagal komunikacijos pobūdị tinklaraščiai sujungia tradicinès spausdintos ir transliuojamos žiniasklaidos formas ir mažas grupių diskusijas'.

Tačiau tinklaraščiai skiriasi tiek nuo tradicinès žiniasklaidos (nes tikslinè auditorija nèra kiekvienas potencialus skaitytojas), tiek nuo vienas - vienam arba vienas - konkrečiai apibrěžtai žmoniu grupei komunikacijos. Tai yra kanalas, suteikiantis visiems galimybę skelbti turini, kuris yra prieinamas kiekvienam, gebančiam ji susirasti ${ }^{10}$.

Interneto naudotojai tinklaraščius ar juose publikuojamą turini gali susirasti per paieškos sistemas. Paprastai kuo daugiau tinklaraščiai turi irašų, tuo labiau jie yra matomi paieškos sistemose. Be to, interneto naudotojai pasitelkdami RSS funkciją turi galimybę užsiprenumeruoti tinklaraščių skelbiamą turinị, taip sutaupydami turinio paieškos laiko ir išvengdami nuolatinio lankymosi juos dominančiuose tinklaraščiuose ieškant naujų įrašų.

Tinklaraščiai padeda išvengti tradicinès žiniasklaidos dominavimo, suteikia galimybę bet kuriam individui išsakyti savo nuomonę ir vertinimus ivvairiomis temomis, potencialiai pasiekti masinę auditoriją. Mokslininkų tyrimai rodo, kad tinklaraščių skaitytojai vertina juos kaip patikimus informacijos šaltinius (net labiau už tradicines žiniasklaidos priemones).

Galima išskirti dvi pagrindines priežastis, kodèl tinklaraščių skaitytojai laiko šias priemones patikimomis. Pirmiausia, tinklaraščiuose dažnai tam tikros temos ar ịvykiai analizuojami gerokai išsamiau negu tradicinèje žiniasklaidoje, pateikiant daugiau faktų ar statistinės medžiagos. Be to, dažniausiai sudètingos temos analizuojamos lengvai suprantama ir priimtina kalba. Antra, palyginti su tradicinèmis žiniasklaidos

8 Vesnic-Alujevic, L. Communicating with voters by blogs? Campaigning for the 2009 European Parliament elections. Discourse \& Communication. 2011, vol. 5, No. 4, p. 413-428.

9 Woodly, D. New competencies in democratic communication? Blogs, agenda setting and political participation. Public Choice. 2008, vol. 134, p. 109-123.

${ }^{10}$ Dean, J. Blog Theory. Feedback and Capture in the Circuits of Drive. Cambridge: Polity Press, 2010, p. 143. 
priemonėmis, skaitytojai tinklaraščius suvokia kaip labiau autentišką komunikacijos formą. Tinklaraščių įrašuose pateikiama tinklaraštininko nuomonè ir vertinimai tam tikra tema, o skaitytojams paliekamos interpretacijos ir galutinių išvadų galimybès ${ }^{11}$.

Tinklaraščius gali rašyti nebūtinai vienas asmuo, tačiau ir kelių asmenų grupès ar net bendruomenės. Pagal tinklaraščių rašytojų skaičių yra išskiriami:

1. asmeniniai tinklaraščiai (kuriuos rašo vienas konkrečiai įvardytas asmuo);

2. grupiniai tinklaraščiai (kuriuos rašo grupè nuolatinių ir aiškiai ịvardytų autorių);

3. bendruomeniniai tinklaraščiai (kuriuose kiekvienas gali skelbti tinklaraščių ịrašus) $)^{12}$.

Kai kuriais atvejais sunku rasti aiškią ribą tarp grupinių ir bendruomeninių tinklaraščių, kai grupe tinklaraščius administruojančių asmenų peržiūri ir tvarko labai didelès grupès žmonių įrašus. Tačiau nepriklausomai nuo to, ar tinklaraštis yra individualus ar grupinis, jo turinys vis tiek lieka individualus, nes kiekvienas tinklaraščio įrašas yra daromas vieno autoriaus ${ }^{13}$.

Kalbant apie tinklaraščių turinio analizę galima išskirti tris matmenis, kurie atskleidžia kiekvieno iš šių internetinių kanalų ypatybes:

1. Turinio ašis (vidinis asmeninis - teminis). Ar tinklaraštyje dominuoja vien tik asmeninès temos, patirtys ir emocijų raiška, ar koks nors vienas aiškiai apibrèžtas tematinis interesas?

2. Krypties ašis (monologas - dialogas). Ar tinklaraštis naudojamas tik informacijos sklaidai, ar siekiama diskusijų su auditorija?

${ }^{11}$ Ekdale, B., Namkoong, K., Fung, T.K.F, Perlmutter, D.D. Why blog? (then and now): exploring the motivations for blogging by popular American political bloggers. New Media Society. 2010, vol. 12, No. 2, p. 217-234.

12 Bar-Ilan, J. Information hub blogs. Journal of Information Science. 2005, vol. 31, No. 4, p. 297-307.

${ }^{13}$ Quiggin, J. Blogs, wikis and creative innovation. International Journal of Cultural Studies. 2006, vol. 9, No. 4, p. 481-496. 
3. Stilistikos ašis (intymiai subjektyvus - objektyvus). Ar tinklaraštyje pateikiamos vien tik asmeninès nuomonès, net nebandant jų argumentuoti, ar pretenduojama $\mathfrak{i}$ objektyvumą pateikiant faktus ir argumentus? ${ }^{14}$

Visi tarpusavyje susieti tinklaraščiai sudaro tinklaraščių ekosistemą (angl. blogosphere). Šis sąsajomis ir nuorodomis susietas tinklas nuolat plečiasi ir auga. Skirtingų tematikų tinklaraščiai sudaro atskiras mažesnes tematines ekosistemas. Pavyzdžiui, tarpusavyje susieti politiniai tinklaraščiai sudaro politinių tinklaraščių ekosistemą.

Apibendrinat pagrindines tinklaraščiu savybes ir komunikacijos procesams padarytus pokyčius galima konstatuoti, kad tinklaraščiai iš dalies ištrina ribą tarp to, kas yra vieša ir privatu, tarp to, kas yra individualu ir bendruomeniška, ir tarp to, kas yra faktai ir nuomonè ${ }^{15}$.

\section{Tinklaraščiai politinès komunikacijos procesuose}

Politiniai tinklaraščiai yra vienas iš tinklaraščių tematinių žanrų. Tradiciškai politiniams tinklaraščiams priskiriami politinėms temoms, naujienoms ir aktualijoms skirti tinklaraščiai, kuriuos gali rašyti tiek politikoje tiesiogiai veikiantys asmenys, tai yra politikai ar jų atstovai (politikų tinklaraščiai), tiek su politika tiesiogiai nesusiję žmonès (tinklaraščiai apie politiką).

Politikų tinklaraščių turinys ir pobūdis priklauso nuo jų autorių. Vieni politiniai tinklaraščiai yra labiau panašūs ị asmeninius internetinius dienoraščius, kiti primena iš įvairių šaltinių surinkto turinio agregato-

${ }^{14}$ Moe, H. Mapping the Norwegian Blogosphere: Methodological Challenges in Internationalizing Internet Research. Social Science Computer Review. 2011, vol. 29, No. 3, p. 313-326.

15 MacDougall, R. Identity, Electronic Ethos, and Blogs: A Technologic Analysis of Symbolic Exchange on the New News Medium. American Behavioral Scientist. 2005, vol. 49, No. 4, p. 575-599. 
rius, treti - tarsi politinès tribūnos, iš kurių politikai nori tik kalbèti, bet ne girdèti žmones ${ }^{16}$.

Tinklaraščiai suteikia vienodas galimybes visiems politiniams veikèjams skleisti savo politines idejjas plačiajai visuomenei, nepriklausomai nuo jų partinès priklausomybės, ideologijos ar turimų finansinių resursų. Tinklaraščiai leidžia drastiškai sumažinti išlaidas politinei komunikacijai, nes bet kuris politikas gali visiškai nemokamai susikurti tinklaraštị ir jame skelbti ịvairaus pobūdžio įrašus. Taip priartẻjama prie tikrosios demokratijos principų, kai politikai virtualioje erdvèje dèl auditorijos dèmesio varžosi ne politinei komunikacijai išleidžiamomis lèšomis, o komunikacinėmis žinutèmis, politinių idèjų ir nuostatų patrauklumu bei argumentais.

Taip pat labai svarbu, kad tinklaraščiai suteikia interaktyvaus dialogo galimybes, nes interneto naudotojai gali ne tik skaityti politikų tinklaraščius, bet ir patys ịsitraukti ì politinę diskusiją rašydami komentarus po politikų irašais. Daugeliu atveju tinklaraščio įrašas yra labiau akstinas inicijuoti ir pradèti diskusiją visuomenei svarbiais klausimai, o ne tik vienkryptès komunikacijos forma tarp tinklaraštininko ir jo publikuojamų įrašų skaitytojų.

Politikų ịrašai ir skaitytojų komentarai sudaro bendrą tinklaraščių turinį, kuriame vienodai vertingi yra tiek politikų skelbiami įrašai, tiek po jais vykstančios skaitytojų ir tinklaraštininkų diskusijos. Tokiu būdu savo turiniu ir forma tinklaraščiai suteikia politikams ir skaitytojams demokratinès tiesioginès komunikacijos patirties, kurios negali pasiūlyti kiti tradicinių medijų kanalai.

Tinklaraščių naudojimas padidina politinès komunikacijos personalizaciją, suasmenina politikos veikèjų ir visuomenės santykį. Čia politikai visuomenei gali parodyti savo „žmogiškąji veidą“, paprastai ir visiems suprantamai argumentuoti priimamus politinius sprendimus ar veiksmus.

${ }^{16}$ Ekdale, B., Namkoong, K., Fung, T.K.F, Perlmutter, D.D. Why blog? (then and now): exploring the motivations for blogging by popular American political bloggers. New Media Society. 2010, vol. 12, No. 2, p. 217-234. 
Politikai, kurie tinklaraščiuose skelbia informaciją apie savo kasdieninę veiklą ir bendrauja su tinklaraščių skaitytojais, išsiskiria iš bendros politikų masės, kuri dažnai paprastiems žmonėms atrodo sunkiai pasiekiama ir neprieinama ${ }^{17}$.

Rašydami tinklaraščius politikai gali naudoti ịvairias strategijas ir įrašų pateikimo formas, suteikti skirtingą reikšmę publikuojamai informacijai, taip pat pateisinti save ar savo sprendimus prieš skaitytojų auditoriją. Politikams, priešingai negu žiniasklaidos priemonių atstovams, tinklaraščiuose nebūtina laikytis žurnalistinio objektyvumo normų. Politikų įrašai tinklaraščiuose dažniausiai grindžiami tam tikrų politinių požiūrių ar įsitikinimų prielaidomis.

Tinklaraščiai yra alternatyvūs informacijos platinimo kanalai, suteikiantys politikams tiesioginę ir nefiltruotą prieigą prie potencialių rinkejjų. Skirtingai nei tradicinèje žiniasklaidoje, kur žurnalistai atrenka, kokią informaciją skelbti visuomenei, tinklaraščiuose politikai patys yra redaktoriai, sprendžiantys, kokị turinị publikuoti visuomenei savo internetiniuose kanaluose. Tinklaraščiai ir kitos socialinių medijų priemonès iš principo praplète viešosios sferos ribas, neribotai padidino aktyvių komunikacijos dalyvių skaičių.

Tinklaraščiai gali būti svarbūs politikams ne tik kaip kanalas tiesiogiai pasiekti auditoriją išvengiant žiniasklaidos, tačiau ir kaip priemonè pasiekti žiniasklaidos atstovus. Pastebima, kad žurnalistai ir žiniasklaidos priemonių redaktoriai dažnai skaito tinklaraščius ieškodami informacijos savo straipsniams ir reportažams ${ }^{18}$. Tokiu būdu politikų tinklaraščių turinys tampa pirminiu informacijos šaltiniu žurnalistams, kurie vis dažniau remiasi interaktyviuose politikų kanaluose pateikiamomis komunikacinėmis žinutèmis.

${ }_{17}$ Albrecht, S., Lübcke, M., Hartig-Perschke, R. Weblog Campaigning in the German Bundestag Election 2005. Social Science Computer Review. 2007, vol. 25, No. 4, p. 504-520.

18 Ekdale, B., Namkoong, K., Fung, T.K.F, Perlmutter, D.D. Why blog? (then and now): exploring the motivations for blogging by popular American political bloggers. New Media Society. 2010, vol. 12, No. 2, p. 217-234. 
Tinklaraščius rašantys politikai irgi dažnai remiasi tradicinės žiniasklaidos priemonėse pateikiamų straipsnių ar reportažų turiniu, kurị tiesiog komentuoja, vertina ar kritikuoja ${ }^{19}$. Todèl galima sakyti, kad yra dvipusė priklausomybė tarp politikų tinklaraščių ir tradicinės žiniasklaidos priemonių - tiek tinklaraštininkai, tiek tradicinių žiniasklaidos priemonių darbuotojai naudoja vieni kitų kuriamą turinị kaip savo informacijos šaltinius.

Tinklaraščiai suteikia galimybę politikams pagreitinti komunikacijos ir politinès informacijos sklaidos procesą, nes tinklaraščiai yra asinchroniška komunikacijos priemonè. Be to, jeigu tradicinès žiniasklaidos priemonès yra ribojamos informacijos publikavimo periodiškumo ciklų (pvz., televizijų naujienų laidos turi konkretų ir nekintamą pasirodymo eteryje laiką, dienraščiai išleidžiami rytais ir pan.), tai informacijos sklaida ir komunikacija tinklaraščiuose bet kuriuo metu gali vykti realiu laiku. Dèl šios priežasties kai kurios politinès naujienos šiandien pirmiausia atsiranda virtualioje erdveje ir tik vèliau patenka ị tradicinès žiniasklaidos eterị ar naujienų puslapius.

Tinklaraščių naudojimą politinès komunikacijos procesuose analizuojantys mokslininkai dažnai tinklaraščius apibūdina kaip nuomonių formavimo ir mobilizacijos instrumentus, suteikiančius politikams galimybių sèkmingai igyvendinti savo tikslus rinkimuose. Būtent šiems tikslams iš pat pradžių ir buvo pradèti naudoti politiniai tinklaraščiai.

Pirmiausia tinklaraščių potencialas buvo atrastas 2003 metais prasidejusioje kovoje dèl Demokratų partijos kandidato nominacijos JAV prezidento posto rinkimams. Buvęs Vermonto valstijos gubernatorius Howardas Deanas 2003-2004 metais iš esmès dèl savo aktyvios ir novatoriškos internetinès rinkimų kampanijos, kurioje ypač svarbią vietą užèmė tinklaraščiai, netikètai tapo vienu iš favoritų kovoje dèl demokratų nominacijos.

Nors H. Deanui ir nepavyko laimèti partijos nominacijos, tačiau ino-

${ }_{19}$ Wall, M. Blogs of war: Weblogs as news. Journalism. 2005, vol. 6, No. 2, p. 153-172. 
vatyvus komunikacijos pavyzdys paskatino politikus visame pasaulyje pradèti naudoti tinklaraščius rinkimų komunikacijos tikslams. Pavyzdžiui, 2004 metų JAV prezidento rinkimų kampanijos metu, kai tarpusavyje kovojo George'as W. Bushas ir Johnas Kerry'is, jau abu kandidatai turejo savo tinklaraščius. Taip pat tinklaraščiai rinkimų komunikacijos tikslams buvo gana plačiai naudojami per 2005 metais vykusius Didžiosios Britanijos visuotinius rinkimus, Danijos Parlamento rinkimus, Naujosios Zelandijos visuotinius rinkimus, Vokietijos Bundestago rinkimus ${ }^{20}$.

Iš karto buvo pastebèta, kad tinklaraščiai yra ypač naudingi politikams bandant pritraukti jaunesniąją rinkèjų auditorijos dalį, kurią pasiekti tradicinèmis žiniasklaidos priemonėmis darosi kaskart sunkiau, nes jauni žmonès vis mažiau laiko praleidžia skaitydami laikraščius ar žiūrèdami televiziją.

Svarbu pažymėti, kad tinklaraščiai gali būti naudojami ir yra labiau naudingi politikams ne kaip trumpojo laikotarpio komunikaciniai kanalai prieš rinkimus, tačiau kaip nuolatinès komunikacijos priemonès, leidžiančios užmegzti ilgalaikius ryšius su skaitytojų auditorijomis. Tinklaraščiai yra itin tinkama priemonè sužinoti visuomenès arba tam tikros rinkejjų grupès nuomonę ir vertinimus ịvairiais klausimais, nustatyti jų pokyčius ir pasitenkinimą politikų veiksmais ${ }^{21}$.

Mažai tikètina, kad tik prieš rinkimus pradèti rašyti tinklaraščiai galètų atnešti daug naudos politikams, nes suburti tinklaraščių skaitytojų auditoriją reikia nemažai laiko. Be to, artejjant rinkimams ir prasidedant rinkimų vajui žmonès pradeda daug ịtariau žiūrèti ị bet kokius politikų bandymus užmegzti naujus kontaktus.

Lygiai taip pat negerai, kai iškart po rinkimų politikai nustoja rašyti savo tinklaraščius, juos visiškai panaikina arba palieka likimo valiai.

${ }^{20}$ Albrecht, S., Lübcke, M., Hartig-Perschke, R. Under Construction: Weblog Campaigning in the German Bundestag Election 2005“. Politicking Online: The Transformation of Election Campaign Communications. Edited by Costas Panagopoulos. Rutgers university press, 2009, p. 179-199.

${ }^{21}$ Drezner, D.W., Farrell H. Introduction: Blogs, politics and power: a special issue of Public Choice. Public Choice. 2008, vol. 134, p. 1-13. 
Tuomet tinklaraščių skaitytojai nusivilia politiniais veikejjais ir jaučiasi apgauti, o dar kartą sudominti ir užmegzti ryší su ta pačia auditorija politikams pasidaro praktiškai neįmanoma.

Politikams rašant tinklaraščius reikalingas nuolatinis įdirbis ir reguliarumas. Tinklaraščių skaitytojai tikisi, kad nauji įrašai bus daromi kiekvieną dieną ar bent jau keletą kartų per savaitę. Priebėgomis tinklaraščius rašantys politikai neišnaudoja viso interaktyvaus kanalo potencialo, jiems pasidaro sunkiau pritraukti ir išlaikyti skaitytojų auditorijas.

Pastebima, kad visuomenèje plačiai žinomiems ir dažniau tradicinejje žiniasklaidoje minimiems politikams yra lengviau pritraukti tinklaraščių skaitytojų demesį. Be to, šis auditorijos dèmesio pritraukimas kartais net nepriklauso nuo politikų aktyvumo ir ịsitraukimo. Menkiau žinomiems ir rečiau žiniasklaidos dèmesị patraukiantiems politikams reikètų bandyti laužyti nusistovejjusias politinès komunikacijos taisykles, ieškoti naujų komunikacijos tinklaraščiuose formų.

Tačiau didžiausias tinklaraščių potencialas kyla ne tiek iš tiesioginių perskaitymų ar įrašų pasidalijimų skaičiaus, kiek iš įtakos nuomonių lyderiams (kitiems politikams, ịtakingiems visuomenès veikèjams, žurnalistams), kurią tinklaraštininkai igijo per labai trumpą laiko tarpą ${ }^{22}$. Yra mokslinių įrodymų, kad politiniai tinklaraščiai padeda sudaryti politinio elito, tokio kaip kiti politikai ir žurnalistai, dienotvarkę ${ }^{23}$.

Be to, pastebima tendencija, kad vis daugiau informacinio pobūdžio interneto portalų siūlo savo lankytojams tinklaraščių rašymo paslaugas, pvz., Delfi blogas arba Blog.lrytas.lt. Politikams, siekiantiems pritraukti masinės žiniasklaidos dėmesį, yra naudinga rašyti savo tinklaraščius naujienų portalų internetinių dienoraščių skiltyse, nes masinė žiniasklaida, pavyzdžiui, Delfi, kartais viešai publikuoja tinklaraščio skyrelyje esančius politikų ịrašus.

${ }^{22}$ McIntosh, S. Blogs: has their time finally come - or gone? Global Media and Communication. 2005, vol. 1, No. 3, p. 385-388.

${ }^{23}$ Woodly, D. New competencies in democratic communication? Blogs, agenda setting and political participation. Public Choice. 2008, vol. 134, p. 109-123. 
Kalbant apie neigiamus tinklaraščių aspektus derètų išskirti šių interaktyvių kanalų skaitytojų fragmentaciją ir poliarizaciją, nes tyrimai rodo, kad daugelis asmenų skaito tik jų politinius ịsitikinimus atitinkančius ir patvirtinančius tinklaraščius ${ }^{24}$.

Tam įtakos turi tinklaraščių tarpusavio sąsajos, kai politikai savo tinklaraščiuose pateikia nuorodas tik ị savo partijos kolegų ar panašios politinès ideologijos asmenų tinklaraščius, vengdami bet kokių tiesioginių sąsajų su politiniais oponentais. Tad skaitytojai sekdami nuorodomis ir sąsajomis iš vienų politikų tinklaraščių ị kitus tarsi patenka ị uždarą ratą, taip nesusidurdami su priešingais politiniais ịsitikinimais ir nuomonèmis.

Apibendrinant praktinị politinių tinklaraščiu naudojimą ir jų ịtaką politinès komunikacijos procesams galima išskirti gerokai daugiau teigiamų aspektų, neabejotinai pagerinusių politikų ir visuomenès tarpusavio interakcijos kokybę, politinio diskurso prieinamumą ir sąveikos galimybes.

\section{Lietuvos Respublikos Seimo narių naudojimosi tinklaraščiais analizè}

Siekiant išsiaiškinti Lietuvos politikų naudojimosi tinklaraščiais ypatybes, atliktas tyrimas, kurio metu analizuota 2008-2012 metų Lietuvos Respublikos Seimo narių komunikacija tinklaraščiuose. Tyrimo analizei buvo pasirinktas laikotarpis nuo $2012 \mathrm{~m}$. sausio $1 \mathrm{~d}$. iki $2012 \mathrm{~m}$. lapkričio $16 \mathrm{~d}^{25}$

Nurodytas tyrimo laikotarpis pasirinktas atsižvelgiant ị $2012 \mathrm{~m}$. spalio $14 \mathrm{~d}$. vykusius Seimo rinkimus, nes siekta tiek išsiaiškinti ilgojo laikotarpio komunikacijos tinklaraščiuose ypatybes, tiek nustatyti, ko-

${ }^{24}$ Ekdale, B., Namkoong, K., Fung, T.K.F, Perlmutter, D.D. Why blog? (then and now): exploring the motivations for blogging by popular American political bloggers. New Media Society. 2010, vol. 12, No. 2, p. 217-234.

${ }^{25}$ Būtent $2012 \mathrm{~m}$. lapkričio 16 d. i pirmajị posèdi susirinko ir kadenciją pradèjo 2012-2016 metų Lietuvos Respublikos Seimo nariai 
kią ịtaką politikų naudojimuisi tinklaraščiais daro artëjantys rinkimai ir periodas po jų.

Atliekant tyrimą ir vykdant parlamentarų tinklaraščių paiešką virtuali politiko erdve buvo laikoma tinklaraščiu, jeigu atitiko bent tris iš penkių išvardytų požymių: 1) atvirkščiai chronologiška įrašų tvarka; 2) irašų komentavimo galimybès; 3 ) nuorodos ị kitus tinklaraščius; 4) sąsajos įrašuose; 5) įrašų archyvas.

Taip pat politiko tinklaraštis ị tyrimo imtị buvo įtraukiamas tik tada, jeigu Seimo nario tinklaraštyje buvo padarytas bent vienas įrašas tiriamuoju laikotarpiu (tai yra nuo $2012 \mathrm{~m}$. sausio $1 \mathrm{~d}$. iki $2012 \mathrm{~m}$. lapkričio $16 \mathrm{~d}$.)

Atlikus tyrimą nustatyta, kad 2008-2012 metų Seimo kadencijos pabaigoje tinklaraščius rašè 10,8 proc. parlamentarų (15 Seimo narių iš $\left.139^{26}\right)$. Tiesa, reikia paminèti, kad virtualioje erdveje buvo rasti dar keli Seimo nariams priklausę tinklaraščiai, tačiau paskutiniai įrašai šiuose interaktyviuose kanaluose buvo daryti daugiau negu prieš metus, todèl jie buvo laikomi neaktyviais ir į bendrą tyrimo imtị neịtraukti.

Analizuojant tinklaraščius rašiusius Seimo narius pagal partinę ir frakcinę priklausomybę nustatyta, kad aktyviausiai tinklaraščius politinei komunikacijai naudojo Tẻvynès sąungos-Lietuvos krikščionių demokratų frakcijos (6 parlamentarai, kurie sudare 40 proc. visų tinklaraštininkų) ir Mišrios Seimo narių grupès frakcijos nariai (4 politikai - 26,6 proc. visų parlamentarų tinklaraštininkų). Taip pat reikia paminèti, kad po vieną arba kelis tinklaraštininkus buvo iš „Tvarkos ir teisingumo“, Liberalų ir centro sąjungos, Liberalų sąjūdžio ir Lietuvos socialdemokratų partijos frakcijų.

Iš 2008-2012 metų Seimo kadencijos pabaigoje buvusių parlamentinių frakcijų nė vieno tinklaraštininko virtualioje erdvèje neturejjo Darbo partijos ir Krikščionių partijos frakcijos.

${ }^{26}$ Kadenciją 2008-2012 m. Seimas baigė ne visos sudėties - 2011 m. rudenị tragiškai žuvus parlamentarui Juozui Palioniui, o 2012 m. birželio mėn. užgesus Justino Karoso gyvybei, Seimo kadencijos pabaigoje dirbo 139 parlamentarai. 


\section{1 iliustracija. Lietuvos Respublikos Seimo narių tinklaraščiai pagal partinę ir frakcinę priklausomybę}

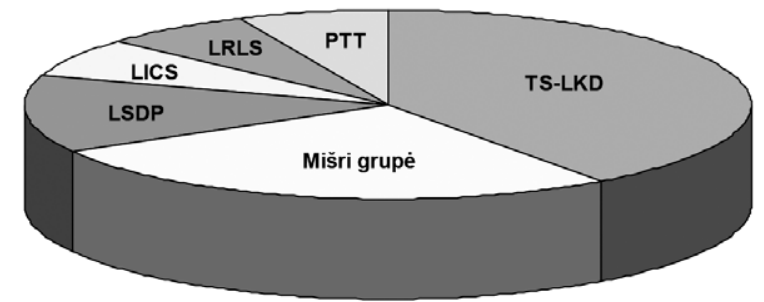

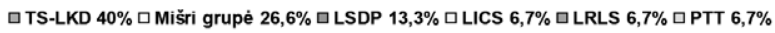

Išanalizavus politikų pasirinktas tinklaraščių platformas nustatyta, kad 6 Seimo nariai (40 proc. visų tinklaraščius rašiusių politikų) savo interaktyvius kanalus buvo sukūrę specialiose naujienų portalų tinklaraščių sekcijose. Keturi parlamentarai tinklaraščius turèjo populiariausio Lietuvos naujienų portalo Delfi.lt skiltyje Blog.delfi.lt. Dar dviejų Seimo narių tinklaraščiai buvo naujienų portalo „Vakarų ekspresas“ skiltyje ve.lt/blog. Šių parlamentarų tinklaraščių vietos pasirinkimą galima aiškinti ne tik siekiu tiesiogiai patraukti skaitytojų dèmesį, bet ir bandymu patekti ị visuomenėje skaitomų naujienų portalų kuriamų pranešimų srautą, taip gerokai išplečiant savo komunikacinių žinučių pasiekiamą auditoriją.

Kita dalis Seimo narių (26,7 proc. visų tinklaraščius rašiusių parlamentarų) tinklaraščius sukūrè tarptautinèse tinklaraščių platformose: du politikai - lankomiausiame pasaulyje tinklaraščių portale Blogspot.com, dar du - atviro kodo tinklaraščių kūrimo sistemoje Wordpress.com. İdomu pažymèti, kad nè vienas politikas savo tinklaraščio rašymui nepasirinko specializuotų lietuviškų tinklaraščių platformų, tokių kaip Blogas.lt ar Blogr.lt.

Penkių parlamentarų (33,3 proc.) tinklaraščiai buvo įdèti jų asmeniniuose puslapiuose kaip atskira tinklalapio skiltis. Tokia tinklaraščio 
vietos pasirinkimo logika nėra visiškai aiški, nes konkrečiu atveju dažnai sunku rasti skirtumų tarp politikų tinklaraščio ir tinklalapio naujienų skilčių.

Seimo narių tinklaraščių ịrašų intensyvumo analizė atskleidè menkas šių internetinių kanalų išnaudojimo apimtis. Iš viso 15 parlamentarų savo tinklaraščiuose $2012 \mathrm{~m}$. sausio-lapkričio mènesiais padarė 322 irašus. Kiekvienam tinklaraščius rašiusiam parlamentarui per beveik vienuolika 2012 metų mènesių vidutiniškai teko po 21,5 įrašus (apie 2 i̇rašus per mènesị).

Vos keturių politikų tinklaraščiuose (26,7 proc. visų tinklaraščių) nauji ịrašai buvo publikuojami kiek dažniau, tai yra bent jau trys ir daugiau ịrašų per mėnesị. Kituose Seimo narių tinklaraščiuose intensyvumas buvo labai menkas. Nuo vieno iki trijų ịrašų per mėnesị intensyvumas fiksuotas keturių parlamentarų internetiniuose kanaluose (26,7 proc. visų tinklaraščių), o septynių analizuotų politikų tinklaraščių intensyvumas nesiekẻ net vieno ịrašo per mènesị (46,6 proc. visų tinklaraščių).

Dažniausiai artëjant rinkimams politikų komunikacijos apimtys visuose kanaluose stipriai išauga, nes politikos veikejjai visomis priemonėmis siekia atkreipti ị save visuomenès dėmesị ir laimèti potencialių rinkejjų simpatijas. Siekiant nustatyti, kokią ịtaką politikų komunikacijai tinklaraščiuose turejo $2012 \mathrm{~m}$. spalio $14 \mathrm{~d}$. vykę Seimo rinkimai, buvo analizuotas bendras įrašų intensyvumo pasiskirstymas visu tiriamuoju laikotarpiu.

Analizès metu buvo nustatyti du pikiniai politikų komunikacijos tinklaraščiuose laikotarpiai - kovo ir spalio ménesiai. Didžiausias komunikacijos intensyvumas buvo kovo mėnesị, kuomet politikų internetiniuose kanaluose iš viso buvo publikuoti 52 įrašai. Peržiūrẻjus visus šị mènesị politikų tinklaraščiuose paskelbtus pranešimus nepavyko nustatyti vienos ryškiai dominuojančios įrašų tematikos, todèl sunku paaiškinti, kodèl būtent ši ménesị fiksuotos didžiausios turinio apimtys. 


\section{2 iliustracija. Seimo narių komunikacijos tinklaraščiuose intensy-} vumas 2012 metais (pagal ịrašų tinklaraščiuose skaičių)

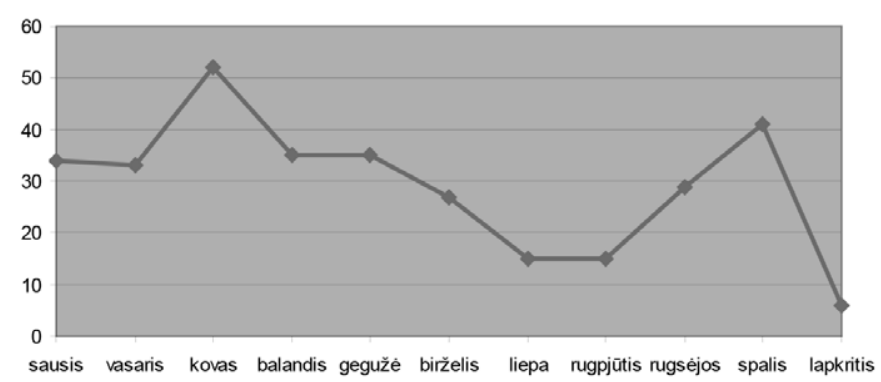

Vasaros mėnesiais fiksuotas mažiausias politikų komunikacijos intensyvumas, kuris rugsèjo mènesi pradejjo didèti ir antrąj piką pasiekè spalio mèn. - eilinių Seimo rinkimų metu. Tačiau svarbu pažymèti, kad politinès komunikacijos intensyvumo lygis nepasiekė kovo mèn. lygio, nes per spalio mėn. politikų tinklaraščiuose buvo paskelbtas 41 ịrašas.

Iš karto po rinkimų - lapkričio mẻn., nustatytas ryškus politikų komunikacijos interaktyviuose kanaluose kritimas iki vasaros mėnesių lygio (bendras komunikacijos intensyvumo lygis liepos, rugpjūčio ir lapkričio mèn. - labai panašus, nes politikų tinklaraščiai buvo analizuojami tik pusę lapkričio mèn., tai yra iki 2012 m. lapkričio 16 d. - 2008-2012 metų Seimo kadencijos pabaigos).

Parlamentarų tinklaraščių ịrašų analizè pagal partinę priklausomybę atskleidẻ kiek didesnị opozicijoje buvusių parlamentarų aktyvumą. Pirmiausia derètų išskirti Mišrios Seimo narių grupès frakcijai priklausiusių politikų ir partijos „Tvarka ir teisingumas“ nario tinklaraščius, kuriuose komunikacija vyko intensyviausiai. Tai iš dalies leidžia patvirtinti prielaidą, kad tinklaraščiai yra itin tinkama priemonė komunikuoti mažiau resursų turintiems ir menkesnio žiniasklaidos dėmesio sulaukiantiems politikams. 
3 iliustracija. Seimo narių tinklaraščių ir juose paskelbto komunikacinio turinio pasiskirstymas pagal partinę ir frakcinę priklausomybę (procentais)

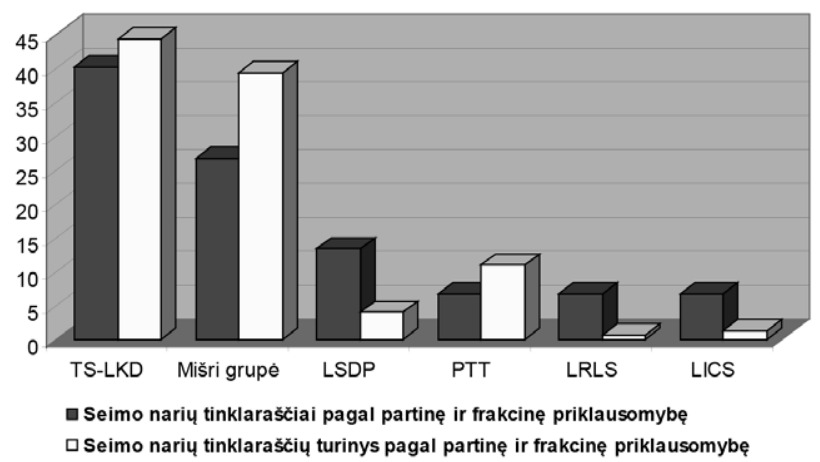

Tačiau kalbant apie visų Seimo narių tinklaraščius tenka konstatuoti, kad visuose politikų internetiniuose kanaluose fiksuotas labai menkas auditorijos grį̌ztamojo ryšio ir interakcijos lygis. Iš esmès visų parlamentarų tinklaraščiuose publikuoti įrašai nesulaukẻ auditorijos įsitraukimo, tai yra komentarų po politikų ịrašais.

Pirmiausia tai būtų galima aiškinti skaitytojams ne itin patraukliu ir įdomiu Seimo narių pateikiamu komunikaciniu turiniu. Dažniausiai parlamentarai skelbdavo gana formalaus pobūdžio informacinius pranešimus, visiškai nebandydami inicijuoti auditorijos grị̌tamojo ryšio ir diskusijų su skaitytojais. Galima apibendrinti, kad politikai tinklaraščius dažniausiai naudojo tiesiog kaip tradicinius vienkryptès komunikacijos kanalus, siekdami tik perduoti savo komunikacines žinutes. 


\section{Išvados}

Nuo pat pirmųjų socialinių medijų kanalų, paremtų antrosios kartos žiniatinklio principais, atsiradimo politikai eksperimentavo ir ieškojo būdų, kaip išnaudoti šias interaktyvias priemones savo tikslams. Būtent tinklaraščiai žymėjo interaktyviosios politinès komunikacijos pradžią, suteikusią naujų galimybių politikų ir visuomenès tarpusavio sąveikai.

Tinklaraščiai, kaip ir kitos socialinių medijų priemonès, suteikia politikams galimybę tiesiogiai pasiekti savo potencialius rinkejjus, užmegzti su jais abipusị dialogą ir diskusijas, daryti įtaką bendram politiniam diskursui. Tačiau šie internetiniai kanalai taip pat reikalauja iš politikų ịsitraukimo ir pastangų, nes tinklaraščių skaitytojai tikisi nuolatinès komunikacijos, tai yra reguliaraus naujo ir kokybiško turinio pateikimo, įdomių diskusijų.

Jeigu kitose socialinių medijų priemonèse, pavyzdžiui, socialinių tinklų svetainėse, politikai gali apsiriboti vos kelių žodžių arba sakinių ịrašais, tai tinklaraščių ǐrašai dažniausiai turi būti ilgesni ir išsamesni, negali nuolat apsiriboti vos vienu kitu žodžiu ar keliais sakiniais. Greičiausiai būtent dèl šios priežasties savo komunikacijai interaktyvioje erdveje Lietuvos politikai daugiau renkasi socialinių tinklų svetaines, o ne tinklaraščius.

Tačiau tinklaraščiai dèl savo pagrindinių ypatybių, tokių kaip nuorodos ir sąsajos įrašuose, įrašų archyvai ir chronologija, turi pranašumų prieš kitas socialinių medijų priemones, nes leidžia politikams ir visuomenei užmegzti bei palaikyti kokybiškesnę politinę komunikaciją, inicijuoti gilesnes ir išsamesnes diskusijas.

Politikai, apsisprendę rašyti tinklaraščius, tam turi skirti nemažai pastangų ir laiko, nes šie interaktyvūs kanalai reikalauja reguliaraus atnaujinimo ir operatyvios reakcijos ị skaitytojų komentarus. Taigi, prieš kurdami savo tinklaraščius politikai turi nuspręsti, ar turès galimybių juos reguliariai atnaujinti ir skelbti kokybišką turinị. Nes politikui geriau išvis neturèti tinklaraščio negu turèti internetinị dienoraštị, kurio turinys apsiriboja formalios informacijos skelbimu arba kuris iš viso nèra reguliariai atnaujinamas. 


\title{
BLOGS AS A TOOL OF POLITICAL COMMUNICATION: CASE OF THE MEMBERS OF THE PARLIAMENT OF THE REPUBLIC OF LITHUANIA
}

\author{
ANDRIUS ŠUMINAS
}

\section{Summary}

Keywords: blogs; political blogs; political communication; communication of the Members of the Parliament; characteristics of blogs.

Blogs signifies a starting point at which interactive media have become firmly established in the processes of political communication providing new opportunities for the expansion in the field of political discourse and its availability for various interested groups or single individuals. Today political blogs, which have become a regular phenomenon in the world, are useful for political actors in the establishment and maintenance of contacts with new potential audiences of voters, as well as in the maintenance of a constant inter-communication between politicians and the public. This article concentrates on the possibility of an application of blogs for political communication processes, as well as the analysis of the interaction features in these virtual channels. The general characteristics of blogs and their defining properties are specifically defined, and their different types, as well as possible dimensions of the analysis, are distinguished in the article. Moreover, a detailed analysis of the benefits granted for politicians by blogs, as well as an examination of the relationship between political blogs and traditional media and their interconnection, is presented. At the end of the publication survey results of the blog use among the Members of the Parliament of the Republic of Lithuania are listed, and these results reveal a small exploitation of this interactive tool for the purposes of political communication in our country.

Iteikta 2012 m. gruodžio 1 d. 